\title{
Deforestation and hunting effects on wildlife across Amazonian indigenous lands
}

\author{
Pedro de Araujo Lima Constantino ${ }^{1}$
}

\begin{abstract}
Deforestation and hunting are main wildlife threats in Amazonia, affecting the ecosystem and dwellers that rely on game meat. Data from 9109 hunted animals from 35 villages of 8 Pano indigenous lands in Brazilian Amazonia were used to build 4 indicators of wildlife status based on ecological models and to analyze the effects of deforestation, hunting pressure, and socioeconomic aspects on wildlife variation. Although variation in wildlife status indicated depletion in certain locations, hunters from most villages continued to hunt their preferred game after decades of intensive hunting. Indigenous hunting resulted in local depletion of species because of the dispersal of animals away from the source of hunting. This local effect can be explained by the permanent hunting of wildlife in the region, the behavior of Pano hunters, and the design and scale of this study analysis. Regionally, however, deforestation and associated factors are the cause of reduced population density and hunting success, extirpating sensitive species. Roads exacerbated hunting effects through disturbance, encroachment, and provision of access to livestock meat at markets. To avoid local depletion, indigenous people must review their subsistence hunting practices, whereas to achieve regional wildlife conservation and to maintain indigenous societies in Amazonia, wildlife habitat loss should be limited.
\end{abstract}

Key Words: Amazonia; game species; habitat loss; indigenous hunting; Katukina; Kaxinawá; road

\section{INTRODUCTION}

The recent decline in populations of large-bodied wildlife species in tropical forests has led to a global bushmeat crisis, threatening forest ecosystems and the people that depend on wild meat (Milner-Gulland et al. 2003). Habitat loss at unprecedented rates and overhunting to supply rural and urban human populations are the main human-mediated disturbances threatening game species (Davidson et al. 2009). These disturbances affect large game communities by dispersing individuals and populations away from the source of disturbance, by reducing population abundance, and by extirpating species, resulting in depleted assemblages where sensitive species are consistently absent (Peres 2001, Laurance et al. 2011). Consequently, in areas with depleted wildlife, smaller prey is hunted farther away from settlements, with a lower meat return rate and from fewer species (Weinbaum et al. 2013, Iwamura et al. 2014).

Although the effects of deforestation and hunting may interact, it is essential to distinguish their individual effects to assess sustainable disturbance levels and impact on wildlife (Laurance and Useche 2009). Habitat loss is identified as one of the most important large-scale threats to large vertebrates, leading to several local extinctions (Kinnaird et al. 2003). Although development initiatives are the main drivers of deforestation in Amazonia, inside protected areas small-scale and subsistence agriculture plays a major role in habitat loss that leads to wildlife depletion. Hunting, in turn, can locally deplete Amazonian wildlife even when indigenous people hunt for subsistence (SouzaMazurek et al. 2000, Peres and Nascimento 2006). For centuries, indigenous people have hunted wildlife, but it is controversial whether their impact alone depletes game species at regional scales (Robinson and Bodmer 1999, Milner-Gulland and Rowcliffe 2007, Levi et al. 2009). In such remote areas, these direct drivers of wildlife depletion can vary associated to socioeconomic variation in human communities (Sirén et al. 2006, Godoy et al. 2010, De la Montaña et al. 2015).
As in other Neotropical forests, Amazonian indigenous groups increasingly hunt in undisturbed and altered habitats (Smith 2005). Hence, game species in indigenous lands (ILs) are subject to multiple depletion drivers. The indigenous groups of the Pano linguistic family that live in the state of Acre hunt for subsistence in ILs dispersed throughout the state (Constantino 2015). Also, their lands are subject to small-scale and subsistence agriculture inside and in surrounding areas that changes forest cover. An investigation of hunting in their lands can provide insights about the drivers of variation in the hunted wildlife in Amazonian protected areas.

\section{Pano hunting in indigenous lands}

Kaxinawá and Katukina are ethnic groups of the Pano linguistic family with cultural similarities (Cunha and Almeida 2002) that, in Brazil, live in a $70,000 \mathrm{~km}^{2}$ region that has been intensively hunted for decades (Peres and Palacios 2007). Their villages were created over the years since the 1970s, and have populations ranging from 50 to 140 people, with different linkage levels to the cities. The villages in Campinas and Igarapé do Caucho ILs have road access to cities, whereas the other villages have river access to markets (Fig. 1). Hunting is a prestigious male activity. Wildlife is the preferred meat source, which is fundamental to community structure through provision and sharing, and is significant for medicine and cosmology. The preferred preys are large species such as ungulates, large primates, reptiles, and understory birds and are chased whenever encountered. The second preference for prey is smaller species that are hunted incidentally when hunters do not succeed in hunting preferred animals (Kensinger 1995, Lima 2002). The most common hunting strategy is the singleman, one-day search for animals, although there is occasional overnight hunting in more remote areas or hunting with dogs or flashlights for specific prey (Constantino 2015). For several decades, shotguns have mostly replaced the bow and arrow. The ideal hunting territory of a remote Pano village is a $5-\mathrm{km}$ circular area from the center of the village that is exclusively used by village 
members (Constantino 2015). Pano hunters evaluate wildlife abundance by estimating the straight distance, in minutes of walking, to the highest number of preferred animals (Kensinger 1995, Constantino et al. 2008).

Fig. 1. Kaxinawá and Katukina indigenous lands studied in Acre State, Brazilian Amazon. Indigenous lands' labels: (a) Kaxinawá do Igarapé do Cauho, (b) Katukina do Campinas, (c) Kaxinawá da Praia do Carapanã, (d) Kaxinawá do Baixo Rio Jordão, (e) Kaxinawá do Rio Jordão, (f) Kaxinawá/ Ashaninka do Rio Breu, (g) Kaxinawá do Humaitá, and (h) Alto Purus.

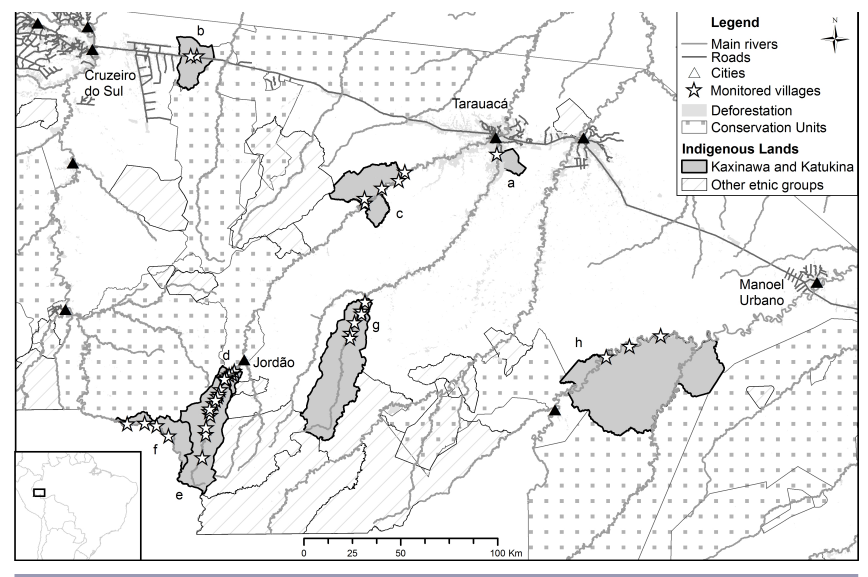

\section{Assessing wildlife status using hunting data}

Variations in game species conservation status and hunting sustainability have been extensively assessed using hunting data, which is easier to collect than animal counts, in tropical areas (Jerozolimski and Peres 2003, Fa et al. 2005, 2015, Ohl-Schacherer et al. 2007, Parry et al. 2009a, Espinosa et al. 2014, OchoaQuintero et al. 2015). Indexes based on hunting data, if carefully designed according to ecological models, can provide reliable information about wildlife species and communities (MilnerGulland and Rowcliffe 2007, Weinbaum 2013).

The central place foraging model links local harvesting intensity to resource depletion. This model assumes that hunting pressure from a settlement within a limited territory first depletes wildlife close to the settlement, and then at increasing distances from the settlement (Sirén et al. 2004, Levy et al. 2011). If the model only includes data for species that are always pursued, the hunting distance from the settlement is an indicator of wildlife status that varies with central place hunting pressure (Alvard et al. 1997, OhlSchacherer et al. 2007, Levi et al. 2011).

In extreme cases of extirpation or drastic reduction in species density, the species is no longer hunted. In the Amazon, certain large primates, birds, and ungulates that are sensitive to habitat disturbance and hunting pressure are prone to extirpation (Robinson 1996, Peres and Palacios 2007). Therefore, their presence in wildlife assemblages is often used as a proxy for wildlife depletion near hunter settlements (Daily et al. 2003, Parry et al. 2009b).
Wildlife populations can also be assessed using indicators derived from the optimal foraging theory. This theory predicts that more animals of lower ranked species are hunted as the cost of hunting them declines compared with higher ranked species (Hames and Vickers 1982, Smith et al. 1983). The addition of new species and increasing frequency of less preferred species in a hunter's prey profile are a response to a decline in abundance of the preferred species (Rowcliffe et al. 2005, Parry et al. 2009a). The factors relating to reduced mean prey weight drive the reduced abundance of preferred species.

In addition to the mean prey weight, the capture per unit of effort (CPUE) for preferred species can be used to evaluate the variation in the abundance of these species. However, this indicator uses a different set of data, the biomass of preferred species and the time spent hunting. This indicator is supported by the behavior of hunters who have to increase their effort in areas with depleted populations of preferred large-bodied species to achieve the required meat return rates (Souza-Mazurek et al. 2000, Sirén et al. 2004, Parry et al. 2009a, b). Therefore, factors that relate to a decrease in CPUE of preferred species cause the reduced abundance of these species.

This research identified the drivers of game variation across villages at the regional level and at the village level using indicators of wildlife status. I developed indicators based on ecological models using hunting data from 35 Kaxinawá and Katukina villages from 8 ILs in Acre, Brazilian Amazonia, to assess different wildlife responses to anthropogenic disturbances. The potential drivers were land use change, hunting pressure, and socioeconomic features of indigenous communities.

\section{METHODS}

\section{Data collection}

The Pano monitors from 35 villages (33 Kaxinawá and 2 Katukina) in 8 ILs (7 Kaxinawá and 1 Katukina) collected data. Between 2004 and 2009, monitors recorded data for hunting effort (number of hunters and time spent hunting) and success (species, weight, and straight distance in minutes from the point of capture to the village). Socioeconomic data, e.g., population, number of hunters and employees, permanent goods, and livestock, were collected via household interviews in all villages in 2004 and 2005 and were updated in 2009 (Constantino et al. 2012a). Deforestation in each village was calculated for the hunting territory $(5-\mathrm{km}$ radius from the village center) using PRODES data for Brazil. Deforestation around villages was estimated to be zero at the Peruvian border near the four villages located in the Kaxinawá/Ashaninka do Rio Breu IL; this is one of the most remote and unchanged forests in Peru (Oliveira et al. 2007).

\section{Indicators of wildlife status}

According the aforementioned ecological models, I assessed wildlife status in response to anthropogenic disturbance across the 35 villages using 4 indicators. (1) The mode of straight hunting distance from the settlement was assessed using the central place forager model. I used the Gaussian kernel density estimator to estimate the distances (Gitzen et al. 2006). (2) The species richness of wildlife assemblages that are sensitive to habitat disturbance and hunting pressure was determined. I calculated the sensitive- 
species richness by combining the number of sensitive hunted species always pursued by the Pano, thereby limiting the analysis to selectively hunted species (Weinbaum et al. 2013). (3) The mean prey weight of hunted animals was obtained from the optimum foraging theory. A fourth indicator was based on data of 21 villages: I used the CPUE (with biomass) for animals of preferred species, using the optimum foraging theory to indicate overall variation in species abundance.

I conducted pairwise Pearson's correlations between the four indicators of wildlife status to assess the differences in information. Data from all indicators were normally distributed. No indicators correlated with monitoring effort $(0.1<\mathrm{r}<0.2 ; \mathrm{p}$ $>0.05$ ), except for the sensitive-species richness. The sampling effort varied between the villages; therefore, I used Mao Tao analysis to correct the differences. The results for the multiple linear regressions using samples corrected for the number of sensitive species were similar to the results for the uncorrected species richness. Therefore, I assumed no effect of sampling on the observed variation and used the uncorrected sensitive-species richness.

\section{Analysis of drivers of wildlife variation}

For each of wildlife status indicators, I used multiple linear regression to detect the drivers of wildlife status across villages. The explanatory variables relating to hunting pressure, land-use change, and socioeconomic condition of Pano villages were transformed ( $\log _{10}$ or square root) when required to achieve normal distribution. I conducted pairwise Pearson's correlations between the 12 continuous explanatory variables before running the regression models to avoid multicolinearity. Variables with fewer correlations and lesser uncertainty were selected. The continuous variables used to build full models were the density of indigenous people in a $5-\mathrm{km}$ radius, village age, indigenous population in the village (hunting pressure), animal unit (socioeconomic condition), and $\log _{10}$ deforested area in a $5-\mathrm{km}$ radius (land use). The nominal variable "road presence" was also used in the model.

I selected the minimal model for each wildlife indicator, excluding unrelated explanatory variables $(\mathrm{p}>0.1)$ from the full model through backward stepwise elimination. An analysis was also performed of all possible subset models checking for the corrected version of the Akaike information criterion (considering a variation of 2.0 as significant), the consistency in variables' entrance in models, and the signals of estimates. I selected all the possible final models for each response variables.

To verify the spatial dependence of the wildlife status indicators across villages and the residuals of the minimal regression models, I used the Moran's I test for each kilometer between 7 and 15; smaller distances had fewer than 28 points and could not be tested for spatial dependence. Reduced sample size prevented testing the spatial dependence of CPUE.

\section{RESULTS}

\section{Pano hunter's prey profile}

The Kaxinawá and Katukina communities hunted 9109 animals comprising 54 wildlife species or higher taxa (e.g., Dasypodidae), among which at least 8 are highly sensitive to human disturbance and 2 are nationally threatened (Table 1 ). The preferred, largebodied vertebrates were the most hunted $(55.7 \%)$ and provided the largest amount of meat (83.95\%). Of the hunted animals, $32 \%$ were sensitive species and contributed to almost half of the consumed meat $(46.25 \%)$. Ungulates, were the most hunted in almost all villages, particularly the white-lipped peccary (Tayassu pecari), which provided up to $60 \%$ of wild meat in some villages. Species of secondary preference that were frequently hunted included paca (Cuniculus paca), agouti (Dasiprocta fuliginosa), armadillos (Dasypodidae), capuchin monkey (Cebus sp.) , squirrels (Sciurus sp.), and coati (Nasua nasua), but they only provided $14 \%$ of the total consumed meat. Although low-ranked species represent the higher number of hunted species, they were rarely hunted $(9.6 \%)$ and provided only $2 \%$ of the total meat. Only $0.1 \%$ of all animals were threatened and provided only $0.2 \%$ total meat consumed.

\section{Drivers of wildlife variation across Pano villages}

The indicators of wildlife status, such as the mean prey weight, sensitive-species richness, and CPUE of preferred species, significantly correlated with each other. In turn, the mode distance of preferred animals from the village did not correlate with other indicators, suggesting that a different process caused its variation (Table 2).

The $51 \%$ variation in mean prey weight across villages in the single significant minimal model was because of deforestation and presence of roads (Tables 3 and 4). Clearing the first 10 hectares of forests near villages resulted in prey weighing $3 \mathrm{~kg}$ less. However, the rate of prey size reduction decreased as deforestation increased. Hunters in roadside villages harvested animals that averaged $6 \mathrm{~kg}$ more than those of riverside villages. The variation in CPUE of preferred species and sensitive-species richness in the minimal models was explained by deforestation, respectively accounting for $30 \%$ and $59 \%$ of the variation (Tables 3 and 4). Losing the first 10 hectares of forest in a $5-\mathrm{km}$ radius around the villages resulted in the absence of more than 2 sensitive species in the prey profiles, but the rate of species absence decreased as deforestation increased. Only hunters from four villages in one IL hunted all sensitive species. In terms of hunting success, hunters caught less meat with the same effort in deforested areas. After the first 10 hectares of the forest were cleared near villages, hunting decreased to $0.65 \mathrm{~kg} / \mathrm{ha}$, which further decreased as deforestation increased. No explanatory variable proxy for hunting pressure was related to mean prey weight, CPUE, or sensitive-species richness. Conversely, the single significant minimal regression model explained that $30 \%$ of the variation in hunting distance of preferred animals hunted away from villages was due to hunting pressure, represented by the density of indigenous people and road presence (Tables 3 and 4). According to this model, an addition of 100 Pano people within $5 \mathrm{~km}$, regardless of whether they belonged to the same village, or a combination of population growth between neighboring villages, would result in Pano people hunting most of their preferred prey approximately $230 \mathrm{~m}$ farther away. Hunters in roadside villages hunted animals approximately $1715 \mathrm{~m}$ farther away from the village center than hunters from riverside villages. Deforestation was not associated with hunting distance from the village. No indicator of wildlife variation was related with the socioeconomic factors analyzed. 
Table 1. Wildlife species hunted by Pano communities in Acre, Brazilian Amazon, during this study. Preferred species (1), secondary species (2), and low-ranked species (3) are indicated according to Cunha and Almeida (2002) and Constantino et al. (2008). For some analysis in this study we grouped 2 and 3 representing species of secondary preference.

\begin{tabular}{|c|c|c|c|c|c|}
\hline Scientific name & Common name & No. of animals & Weight of animals & Preference & Sensitive species \\
\hline Tayassu pecari & White-lipped peccary & 1335 & $24,455.6$ & 1 & $\mathrm{X}$ \\
\hline Pecari tajacu & Collared peccary & 1267 & $16,049.0$ & 1 & \\
\hline Mazama americana & Red brocket deer & 695 & $15,381.8$ & 1 & \\
\hline Tapirus terrestris & Lowland tapir & 68 & 6786.0 & 1 & $\mathrm{X}$ \\
\hline Alouatta seniculus & Howler monkey & 539 & 3343.5 & 1 & $\mathrm{X}$ \\
\hline Chelonoides denticulate & Yellow-footed tortoise & 536 & 3161.3 & 1 & $\mathrm{X}$ \\
\hline Ateles chamek & Spider monkey & 258 & 1937.5 & 1 & $\mathrm{X}$ \\
\hline Caiman sp. & Caiman & 177 & 1614.5 & 1 & \\
\hline Lagothrix lagotricha & Woolly monkey & 72 & 536.2 & 1 & $\mathrm{X}$ \\
\hline Mitu tuberosum & Razor-billed currasow & 96 & 457.1 & 1 & $\mathrm{X}$ \\
\hline Mazama gouazoubira & Brown brocket deer & 10 & 136.0 & 1 & \\
\hline Pipile cujubi & Piping guan & 18 & 37.5 & 1 & $\mathrm{X}$ \\
\hline Cuniculus paca & Paca & 524 & 3933.1 & 2 & \\
\hline Dasypodidae $^{\dagger}$ & Armadillo & 427 & 2368.5 & 2 & \\
\hline Dasiprocta fuliginosa & Agouti & 411 & 1812.2 & 2 & \\
\hline Nasua nasua & Coati & 313 & 1450.8 & 2 & \\
\hline Cebus apela & Brown capuchin & 266 & 1031.1 & 2 & \\
\hline Sciurus sp..$^{\ddagger}$ & Squirrel & 636 & 657.5 & 2 & \\
\hline Penelope jacquacu & Spix’s guan & 228 & 421.7 & 2 & \\
\hline Tinamus guttatus & Large tinamous & 200 & 326.1 & 2 & \\
\hline Hydrochaeris hydrochaeris & Capybara & 13 & 291.0 & 3 & \\
\hline Psophia leucoptera & Pale-winged trumpeter & 132 & 251.3 & 2 & \\
\hline Dinomys branickii & Pacarana & 31 & 236.0 & 3 & \\
\hline Pithecia sp. & Saki monkey & 68 & 203.0 & 3 & \\
\hline Myoprocta pratii & Acouchi & 162 & 183.8 & 3 & \\
\hline Cebus albifrons & White-fronted capuchin & 45 & 162.5 & 3 & \\
\hline Aotus nigriceps & Night monkey & 88 & 119.8 & 3 & \\
\hline Priodontes maximus ${ }^{\#}$ & Giant armadillo & 4 & 95.0 & 3 & \\
\hline Myrmecophaga tridactyla\# & Giant anteater & 4 & 87.0 & 3 & \\
\hline Ara sp." & Macaw & 53 & 74.9 & 3 & \\
\hline Saimiri sciureus & Squirrel monkey & 53 & 60.7 & 3 & \\
\hline Tinamus tao & Grey tinamous & 24 & 55.8 & 2 & \\
\hline Callicebus moloch & Titi monkey & 44 & 53.1 & 3 & \\
\hline Saguinus sp! & Tamarin & 53 & 44.2 & 3 & \\
\hline Amazona sp. & Parrot & 34 & 31.8 & 3 & \\
\hline Crypturellus cinereus & Small tinamous & 30 & 21.6 & 3 & \\
\hline Ramphastos sp. & Toucan & 26 & 20.5 & 3 & \\
\hline Ortalis guttata & Speckled chachalaca & 23 & 16.8 & 3 & \\
\hline Crypturellus soui & Little tinamous & 25 & 16.3 & 3 & \\
\hline Rallidae & Rail & 23 & 15.0 & 3 & \\
\hline Coendou sp. & Quandu & 3 & 15.0 & 3 & \\
\hline Tinamous major & Small tinamous & 15 & 12.5 & 2 & \\
\hline Crypturellus sp.3 & Small tinamous & 15 & 11.9 & 3 & \\
\hline Crypturellus sp. 2 & Small tinamous & 18 & 11.6 & 3 & \\
\hline Odontophorus sp. & Wood quail & 11 & 6.9 & 3 & \\
\hline Jabiru mycteria & Jabiru & 1 & 6.0 & 3 & \\
\hline Harpia harpyja & Harpy eagle & 1 & 5.0 & 3 & \\
\hline Columbidae & Dove & 14 & 4.3 & 3 & \\
\hline Anatidae & Duck & 3 & 4.0 & 3 & \\
\hline Accipitridae & Kite & 3 & 2.5 & 3 & \\
\hline Tupinambis teguixin & Common tegu & 2 & 2.0 & 3 & \\
\hline Psarocolius sp. & Oropendola & 5 & 1.9 & 3 & \\
\hline Psittacidae & Macaw & 5 & 1.9 & 3 & \\
\hline Pteroglossus sp. & Aracari & 2 & 0.9 & 3 & \\
\hline Total & & 9109 & $88,023.3$ & & \\
\hline $\begin{array}{l}{ }^{\dagger} \text { Dasypus novemcinctus, Das } \\
{ }^{+} \text {S. ignitus and } S \text {. spadiceus. } \\
{ }^{8} \text { P. irrorata or } \text { P. monachus. } \\
\text { IS. imperator, S. fusicolor, } S \\
\text { "taxa containing more than } \\
{ }^{*} \text { Threatened species accordi }\end{array}$ & $\begin{array}{l}\text { eucus, and possibly } S . \text { my } \\
\text { ies but with uncertain ide } \\
\text { International Union for }\end{array}$ & cor & 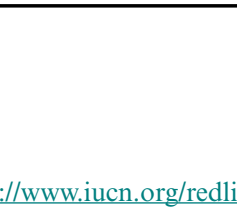 & & \\
\hline
\end{tabular}


Table 2. Pearson correlation matrix between simple indicator variables of wildlife depletion in Pano villages (upper) and excluding roadside villages (bottom) in Acre, Brazilian Amazon.

\begin{tabular}{lccc}
\hline \hline Indicators of wildlife status & $\begin{array}{c}\text { Mean } \\
\text { prey } \\
\text { weight }\end{array}$ & $\begin{array}{c}\text { CPUE } \\
\text { preferred } \\
\text { species }\end{array}$ & $\begin{array}{c}\text { Number of } \\
\text { sensitive } \\
\text { species }\end{array}$ \\
\hline Mean prey weight & 1 & & \\
CPUE of preferred species & $0.83^{* *}$ & 1 & \\
& $0.82^{* *}$ & & \\
Number of sensitive species & $0.54^{*}$ & $0.62^{* *}$ & 1 \\
& $0.73^{* *}$ & $0.59^{* *}$ & \\
Mode distance of preferred & 0.33 & 0.00 & -0.04 \\
species hunted from the village & 0.19 & 0.14 & 0.25 \\
\hline CPUE indicates capture per unit of effort. & & \\
${ }^{*} \mathrm{p}<0.01 ; * \mathrm{p}<0.05$. & & & \\
\end{tabular}

Table 3. Backward stepwise regression models for all response variables at the village level.

\begin{tabular}{lccccc}
\hline \hline Response variable & $\mathrm{R}_{\text {adj }}^{2}$ & DF & F ratio & $\mathrm{p}$ & $\mathrm{n}$ \\
\hline Mean prey weight & 0.51 & 2 & 18.62 & $<0.001$ & 35 \\
CPUE preferred species & 0.30 & 1 & 9.67 & 0.006 & 21 \\
Sensitive species richness & 0.59 & 1 & 49.78 & $<0.001$ & 35 \\
Mode distance of preferred & 0.30 & 2 & 8.42 & 0.001 & 35 \\
species hunted from the village & & & & & \\
\hline CPUE indicates capture per unit of effort; DF, degrees of freedom.
\end{tabular}

These results separated the effects of indigenous hunting and deforestation near villages in two different processes driving wildlife variation. Nevertheless, it was not possible to separate the effects of deforestation and indigenous hunting from the effects of nonindigenous hunting. No information was available on nonindigenous hunting pressures around or encroaching onto IL.

Human-sensitive species were consistently absent in hunters' prey profiles for several villages, particularly the piping guan (Pipile cujubi), razor-billed curassow (Mitu tuberosum), wooly monkey (Lagothrix lagotricha), spider monkey (Ateles chamek), and lowland tapir (Tapirus terrestris). Villages that hunted four or less sensitive species never hunted the piping guan, razor-billed curassow, and tapir, whereas only one hunted the spider monkey and four hunted the wooly monkey. Villages alongside roads did not hunt large monkeys or birds. However, the howler monkey (Alouatta seniculus), the yellow-footed tortoise (Chelonoides denticulate), and the white-lipped peccary were hunted in varying intensities in most villages. Other preferred large-bodied species resilient to anthropogenic disturbances, such as the collared peccary (Pecari tajacu) and the red brocket deer (Mazama americana), were hunted in all villages.

\section{Spatial dependence of indicators across Pano villages}

The mean prey weight and sensitive-species richness across villages were autocorrelated and increased with distances between 7 and $15 \mathrm{~km}(0.19<\mathrm{r}<0.29 ; \mathrm{p}<0.05)$. The hunting distance from the village was not autocorrelated $(-0.04<\mathrm{r}<0.13, \mathrm{p}>0.1)$.
The residuals of the minimal regression models were not spatially dependent. The deforestation explanatory variable correlated with the Moran's I results for mean prey weight and sensitivespecies richness analysis.

Table 4. Explanatory variables included in the final regression models after stepwise and supervised selection.

\begin{tabular}{|c|c|c|c|c|}
\hline $\begin{array}{c}\text { Response variable } \\
\text { Parameters }\end{array}$ & Estimate & SE & t Ratio & Prob $>\mathrm{t}$ \\
\hline \multicolumn{5}{|l|}{ Mean prey weight } \\
\hline Intercept & 18.90 & 1.66 & 11.38 & $<0.001$ \\
\hline Log deforested area & -3.36 & 0.61 & -5.49 & $<0.001$ \\
\hline Road presence & 3.02 & 0.64 & 4.72 & $<0.001$ \\
\hline \multicolumn{5}{|l|}{ CPUE of preferred species } \\
\hline Intercept & 2.84 & 0.46 & 6.13 & $<0.001$ \\
\hline Log deforested area & -0.65 & 0.21 & -3.11 & 0.006 \\
\hline \multicolumn{5}{|l|}{ Sensitive species richness } \\
\hline Intercept & 10.51 & 0.86 & 12.24 & $<0.001$ \\
\hline Log deforested area & -2.68 & 0.38 & -7.06 & $<0.001$ \\
\hline \multicolumn{5}{|c|}{ Mode distance of preferred species to village center } \\
\hline Intercept & 72.76 & 16.71 & 4.35 & $<0.001$ \\
\hline Road presence & 31.50 & 10.71 & 2.94 & $<0.01$ \\
\hline $\begin{array}{l}\text { Density of indigenous } \\
\text { people }\end{array}$ & 6.60 & 2.83 & 2.33 & 0.03 \\
\hline
\end{tabular}

\section{DISCUSSION}

\section{Wildlife status across Pano villages}

Even after several decades of wildlife harvesting and current intensive hunting pressure in a lightly deforested region, most Kaxinawá and Katukina communities still have preferred largebodied species as their main meat source. The Pano hunt more ungulates, similar to Amazonian communities where game is not severely depleted (Alvard et al. 1995, Robinson and Bodmer 1999), including other Kaxinawá in Peru (Navarro 2004). This overall pattern suggests that wildlife is not depleted; even threatened species are rarely hunted because hunters prefer other species. Nonetheless, there was variation in wildlife status across villages.

Some villages substituted their main hunting for ungulates with hunting for smaller and less preferred but resilient species, which created a gradual shift in the mean prey weight, indicating depleted wildlife assemblages. In particular, villages located in the ILs of Kaxinawá da Praia do Carapanã and Baixo Rio Jordão have drastically changed their prey profile, including lots of animals of less preferred species. This pattern can be because of several factors, including persistent hunting (Iwamura et al. 2014), and is observed across multiple sites in a protected area in the same region (Ramos 2005) as well as at larger tropical spatial scales (Jerozolimski and Peres 2003, Fa and Brown 2009). Another indication of localized game depletion is the absence of razorbilled curassow, piping guan, spider monkey, wooly monkey, and tapir in prey profiles from several villages. Except for the four villages in the IL of Kaxinawá/Ashaninka do Rio Breu, at least 
one species was absent in the prey profile of all the villages. In the Neotropics, these species are the most sensitive to anthropogenic disturbance and are likely to be the first locally extirpated animals, being consistently absent among hunted species at single depleted sites (Daily et al. 2003, Parry et al. 2009b) and across sites in the Amazon basin (Peres 2000). In addition, the variation of meat return rate across Pano villages indicates a decline in preferred game abundance, particularly ungulates. This was also observed in Peruvian communities where the decline in abundances of peccaries and tapir over 10 years resulted in a decline in the meat return rate (Bodmer et al. 1997). As a result, Pano living in depleted villages changed their social and cultural practices. They frequently consumed small livestock or fish and increased their purchase of meat from the markets, like the two villages in the Katukina do Campinas and the one in the Kaxinawá do Igarapé do Caucho ILs(Lima 2001, Constantino et al. 2012b).

Considering the optimal foraging theory, the CPUE for Pano hunters declined because of a change in assemblage structure, which was because of reduced abundances of preferred species and reduced species composition due to extirpation of some sensitive species. However, these indicators do not assume the underlying cause of wildlife variation a priori (Rist et al. 2009). Therefore, several factors could be driving wildlife depletion and status variation across the villages.

Conversely, the hunting distance from the village assumes that hunting pressure is the main driver of wildlife variation, which conforms to the premises of the central place forager model (Levi et al. 2009). Hence, the pattern observed across Pano villages could be related to indigenous hunting pressure. However, the effect of hunting on animal populations is not defined. If it affects population abundances, the increase in hunting distance from the village is related to reduced abundance of tropical game (Hill et al. 1997, Ohl-Schacherer et al. 2007) and lower meat return rate in other indigenous groups in the Amazon (Alvard et al. 1997, Sirén et al. 2004). These associations were not observed across Pano villages, where preferred animals were hunted farther away in villages with higher hunting pressures; however, wildlife assemblages were not considerably depleted.

\section{Regional effects of deforestation on wildlife}

The regression analysis results suggest that deforestation and indigenous hunting induced different responses in wildlife species, whereas the presence of roads exacerbated the effects of both drivers. Pano hunting and deforestation had different effects on game species because there were no associations between these explanatory variables, no correlation between the wildlife status indicator "hunting distance from the village" and the other three indicators, the models that explained the variation of wildlife status across villages differed, and there were different patterns of spatial dependence of indicators.

Across Pano villages, deforestation depleted wildlife by significantly inducing shifts in large game abundances and by declines in sensitive-species richness, leading to an increase in the effort needed to obtain meat from preferred species. This driver apparently affects wildlife at larger ecological spatial scales, given the autocorrelation of indicators and deforestation index across Pano villages. The rate of loss of two species related to deforestation across Pano villages is similar to the rate of species loss due to forest cover loss in a nearby region in Amazonia (Ochoa-Quintero et al. 2015).
Forest cover loss has an important influence in the depletion of tropical wildlife; it has been used to estimate future reductions in population range and size and species extinction (Kinnaird et al. 2003; Soares-Filho et al. 2006). Despite local hunting, regional deforestation has caused the loss of many game species across forest fragments in Mexico (Urquiza-Hass et al. 2009) and the Brazilian Amazonia (Michalski and Peres 2007). Nevertheless, in Amazonia, hunters catch more ungulates in primary forests in heterogeneous landscapes in the eastern region (Parry et al. $2009 b$ ), whereas ungulates hunted by local people declined in response to increasing deforestation density in another protected area in Acre (Ramos 2005).

Habitat loss and land-use practices inside Pano ILs corresponded to slash-and-burn agriculture and small-scale pastures bordered by forests prone to fire and fragmentation (Norris et al. 2008). In Amazonia, deforestation and associated processes such as fire (Barlow and Peres 2006) and fragmentation (Michalski and Peres 2007) have directly affected large game species by reducing their population and home range, and have indirectly affected resources, changing climate, and other ecological interactions (Laurance et al. 2011, Michalski and Peres 2007, Laurance and Useche 2009). Deforestation, fire, and fragmentation are related to the nonrandom extirpation of large frugivorous primates, birds, and the lowland tapir; whereas other game species may be resilient because of their generalism (Peres 2000). Therefore, these processes may be associated with deforestation that has directly depleted game species at the regional level in Pano ILs.

\section{Local effects of indigenous hunting on wildlife}

The Pano hunting pressure, in turn, was related to the variation in wildlife distribution near villages, but it did not cause game depletion at the regional level. Populations of preferred game species moved away from villages with more hunters and more wildlife consumption, which consequently changed the hunting distance from the village. This process affected wildlife responses across indigenous villages in Acre operating at the local level, closer than $7 \mathrm{~km}$, and only within the indigenous hunting territory. The spread of animals away from the village center because of hunting pressure was reported for tropical areas where hunters go for one-day-walking, subsistence hunting trips (Stearman 1990). For example, local hunting was not responsible for regional wildlife depletion in several tropical forest regions, such as Mexico (Urquiza-Hass et al. 2009) and Africa (Fa et al. 2005). The hunting effect is local and does not extirpate primate populations at a regional level, particularly if the area is surrounded by underexploited forest (Levi et al. 2009).

The relatively small and localized effect of indigenous hunting on wildlife variation may be related to ecological factors as well as to the design of hunting research. Major declines in mammal densities due to hunting are more likely to occur in previously unhunted sites than in those already exploited because hunters in unaltered forests usually represent the only anthropogenic disturbance to game populations. A selective filter may operate after the initial hunting pressure, whereby tolerant species and population abundances remain stable until other processes begin adding to the negative effect of hunting (Cowlishaw et al. 2005, Fa and Brown 2009, Iwamura et al. 2014). The Pano people hunt in a region affected by centenary intense hunting, but major land conversion has only occurred recently. Some time ago, Pano hunting may have strongly affected current wildlife communities, 
but now they are mainly affected by deforestation. In addition, when hunting pressure is concentrated in a few areas, game populations in larger forest areas may function as a source of individuals for other game populations in adjacent disturbed sink areas (Woodroffe and Ginsberg 1998). Therefore, undisturbed areas near Pano villages may be a source of animals (Constantino et al. 2008), whereas Pano villages surrounded by depleted areas may not have the wildlife population to be a source of animals for hunting territories (Hansen and DeFries 2007).

Severe impacts of hunting were discovered based on metaanalyses of studies with decades of differences, conducted at continental or intercontinental scales (Robinson and Bennett 2004; Fa and Peres 2001) using a small sampling effort but including hunters from different cultures (Peres 2001, Jerozolimski and Peres 2003, Fa et al. 2005). Because of the present study design, the data had little variation in temporal, spatial, and cultural aspects across villages, which could introduce uncertainties (Redford and Robinson 1987, Lupo and Schmitt 2005, Peres and Palacios 2007). The results from Pano ILs clearly differentiated the effects of indigenous hunting and deforestation on wildlife, which are difficult to distinguish (Fa and Brown 2009, Parry et al. 2009b). Because most tropical forest game species sensitive to hunting are also sensitive to habitat loss (Michalski and Peres 2007, Laurance et al. 2012) and fire effects (Barlow and Peres 2006), it is hard to clearly delimit hunting pressure (Rist et al. 2008).

Moreover, the spatial scale of research can alone explain much of the wildlife variation in response to habitat loss (Dumbrell et al. 2008) and human occupancy (Pautasso 2007). Pano hunting had only local effects on wildlife, which may have been suppressed by landscape differences in deforestation. Robinson and Bodmer (1999) claim that indigenous hunting has been sustainable at the landscape level, whereas many species must have been locally extirpated by hunting. Sirén et al. (2004) found that at the local scale a model of hunting sustainability indicated overharvested populations, whereas at regional scales, populations would be sustainably harvested. At a spatial scale similar to that of the present research, species richness is expected to have no relationship with human presence (Pautasso 2007), and the effects of deforestation exceed the effects from local hunting of game animals (Michalski and Peres 2007, Urquiza-Hass et al. 2009).

\section{The effect of roads on indigenous hunting}

In Amazonia, roads have affected hunter-prey systems by changing hunter behavior and prey ecology (Espinosa et al. 2014). Roads had a dual effect on Pano hunting systems. First, they exacerbated the negative effects of indigenous hunting on hunting distance from roadside villages, probably through their associated disturbances (Laurance et al. 2006, Fahrig and Rytwinski 2009) and by increasing poacher access to Pano ILs (Lima 2001). Second, roads are related to a shift in roadside village behavior toward a market-dependent diet. Because ammunition is expensive in the small cities in Acre, sometimes more expensive than livestock meat, the Pano prefer not to shoot small species that have low meat return rates. Hence, in Amazonia (Redford 1993, Jerozolimski and Peres 2003, Sirén and Wilkie 2014), Pano hunters substitute livestock meat for hunting small species and restrict their hunting to large mammals, even when wildlife is depleted. Therefore, CPUE and mean prey weight in these villages reflect human processes more than prey abundances (Ling and Milner-Gulland 2006), and hence, these should not be used to infer wildlife status. Nonetheless, these results are important for understanding the effects of roads on indigenous community behavior and society.

\section{Implications for conservation of game species and indigenous well-being}

Discerning the effects of different drivers of change in game populations is crucial for determining correct conservation action and mitigating the main threats to wildlife. This research indicates a relatively higher importance of deforestation and associated factors than indigenous hunting for regional game depletion in Amazonia. These findings are alarming because of the negative consequences of deforestation to game species even in wellconserved tropical forest regions. Wildlife conservation, therefore, should target this threat instead of blaming subsistence hunting for the massive loss of diversity. Nonetheless, indigenous people should be aware that their hunting pressure leads to local wildlife depletion and consequently affects their communities. The effect of roads on indigenous societies and game populations must be taken into account when conservation is designed on a large scale. In this case, protecting the surroundings of these protected areas and opposing encroachment would help to guarantee the sustainability of wildlife for use by indigenous people and their integrity and autonomy as a society.

Responses to this article can be read online at: http://www.ecologyandsociety.org/issues/responses. php/8323

\section{Acknowledgments:}

I thank the Kaxinawa and Katukina representatives and Comissão Pró-Índio do Acre that conduct the monitoring of hunting; Brian Child, Marianne Schmink, and Robert Fletcher for helpful comments on the first drafts; and Marcio Uehara-Prado and Joseph Lucetti for the support with statistical analysis. The Wildlife Conservation Society and the Gordon and Betty Moore Foundation supported the field work. The Tropical Conservation and Development Program and the School of Natural Resources and Environment at the University of Florida provided the author's assistantship during the master program.

\section{LITERATURE CITED}

Alvard, M. S., J. B. Alcorn, R. E. Bodmer, R. Hames, K. Hill, J. Hudson, R. L. Lyman, R. K. Puri, E. A. Smith, and A. M. Stearman. 1995. Intraspecific prey choice by Amazonian hunters. Current Anthropology 36:789-818. http://dx.doi.org/10.1086/204432

Alvard, M. S., J. G. Robinson, K. H. Redford, and H. Kaplan. 1997. The sustainability of subsistence hunting in the Neotropics. Conservation Biology 11:977-982. http://dx.doi.org/10.1046/ j.1523-1739.1997.96047.x

Barlow, J., and C. A. Peres. 2006. Effects of single and recurrent wildfires on fruit production and large vertebrate abundance in a central Amazonian forest. Biodiversity \& Conservation 15:985-1012. http://dx.doi.org/10.1007/s10531-004-3952-1 
Bodmer, R. E., R. Aquino, P. Puertas, R. Reyes, T. Fang, and N. Gottbenker. 1997. Manejo y uso sustentable de pecaries en la Amazonia Peruana. International Union for the Conservation of Nature and Natural Resources, Regional Office for South America, Quito, Ecuador.

Constantino, P. A. L. 2015. Dynamics of hunting territories and prey distribution in Amazonian indigenous lands. Applied Geography 56:222-231. http://dx.doi.org/10.1016/j.apgeog.2014.11.015

Constantino, P. A. L., H. S. A. Carlos, E. E. Ramalho, L. Rostant, C. Marinelli, D. Teles, and S. F. Fonseca-Junior, R. B. Fernandes, and J. Valsecchi. 2012a. Empowering local people through community-based resource monitoring: a comparison between Brazil and Namibia. Ecology and Society 17(4):22. http://dx.doi. org/10.5751/ES-05164-170422

Constantino, P. A. L., L. B. Fortini, F. R. S. Kaxinawa, A. M. Kaxinawa, E. S. Kaxinawa, A. P. Kaxinawa, L. S. Kaxinawa, J. M. Kaxinawa, and J. P. Kaxinawa. 2008. Indigenous collaborative research for wildlife management in Amazonia: the case of Kaxinawá, Acre, Brazil. Biological Conservation 141:2718-2729. http://dx.doi.org/10.1016/j.biocon.2008.08.008

Constantino, P. A. L., R. A. Tavares, J. L. Kaxinawa, F. M. Macário, E. Kaxinawa, and A. S. Kaxinawa. 2012b. Mapeamento e monitoramento participativo da caça na Terra Indígena Kaxinawá da Praia do Carapanã, Acre, Amazônia Brasileira. Pages 141-153 in A. Paese, A. Uezu, M. L. Lorini, and A. Cunha, editors. Sistema de informações geográficas e a conservação da biodiversidade. Oficina do Texto, São Paulo, Brasil.

Cowlishaw, G., S. Mendelson, and J. M. Rowcliffe. 2005. Evidence of post-depletion sustainability in a mature bushmeat market. Journal Applied Ecology 42:460-468. http://dx.doi.org/10.1111/ j.1365-2664.2005.01046.X

Cunha, M. C., and M. B. Almeida. 2002.Enciclopédia da floresta. First edition. Companhia das Letras, São Paulo, Brasil.

Daily, G. C., G. Ceballos, J. Pacheco, G. Suzán, and A. SánchezAzofeifa. 2003. Countryside biogeography of Neotropical mammals: conservation opportunities in agricultural landscapes of Costa Rica. Conservation Biology 17:1814-1826. http://dx.doi. org/10.1111/j.1523-1739.2003.00298.X

Davidson, A. D., M. J. Hamilton, A. G. Boyer, J. H. Brown, and G. Ceballos. 2009. Multiple ecological pathways to extinction in mammals. Proceedings of the National Academy of Sciences of the United States of America 106:10702-10705. http://dx.doi. org/10.1073/pnas.0901956106

De la Montaña, E., R. del Pilar Moreno-Sánchez, J. H. Maldonado, and D. M. Griffith. 2015. Predicting hunter behavior of indigenous communities in Ecuadorian Amazon: insights from a household production model. Ecology and Society 20(4):30. http://dx.doi.org/10.5751/ES-08032-200430

Dumbrell, A. J., E. J. Clark, G. A. Frost, T. E. Randell, J. W. Pitchford, and J. K. Hill. 2008. Changes in species diversity following habitat disturbance are dependent on spatial scale: theoretical and empirical evidence. Journal of Applied Ecology 45:1531-1539. http://dx.doi.org/10.1111/j.1365-2664.2008.01533. $\underline{\mathrm{X}}$
Espinosa, S., L. C. Branch, and R. Cueva. 2014. Road development and the geography of hunting by an Amazonian indigenous group: consequences for wildlife conservation. PLoS ONE 9(12):e114916. http://dx.doi.org/10.1371/journal.pone.0114916

Fa, J. E., and D. Brown. 2009. Impacts of hunting on mammals in African tropical moist forests: a review and synthesis. Mammal Review 39:231-264. http://dx.doi.org/10.1111/j.1365-2907.2009.00149. $\underline{\mathrm{x}}$

Fa, J. E., J. Olivero, M. A. Farfán, A. L. Márquez, J. Duarte, J. Nackoney, A. Hall, J. Dupain, S. Seymour, P. J. Johnson, D. W. Macdonald, R. Real, and J. M. Vargas. 2015. Correlates of bushmeat in markets and depletion of wildlife. Conservation Biology 29:805-815. http://dx.doi.org/10.1111/cobi.12441

Fa, J. E., and C. A. Peres. 2001. Game vertebrates extraction in African and Neotropical forests: an intercontinental comparison. Pages 203-241 in J. D. Reynolds, G. M. Mace, K. H. Redford, and J. G. Robinson, editors. Conservation of exploited species. Cambridge University Press, Cambridge, UK.

Fa, J. E., S. F. Ryan, and D. J. Bell. 2005. Hunting vulnerability, ecological characteristics and harvest rates of bushmeat species in afrotropical forests. Biological Conservation 121:167-176. http://dx.doi.org/10.1016/j.biocon.2004.04.016

Fahrig, L., and T. Rytwinski. 2009. Effects of roads on animal abundance: an empirical review and synthesis. Ecology and Society 14(1):21. [online] URL: http://www.ecologyandsociety. org/vol14/iss1/art21/

Gitzen, R. A., J. J. Millspaugh, and B. J. Kernohan. 2006. Bandwidth selection for fixed-kernel analysis of animal utilization distributions. Journal of Wildlife Management 70: 334-1344. http://dx.doi.org/10.2193/0022-541x(2006)70[1334:bsffao] 2.0.co; 2

Godoy, R., E. A. Undurraga, D. Wilkie, V. Reyes-García, T. Huanca, W. R. Leonard, T. McDade, S. Tanner, V. Vadez, and TAPS Bolivia Study Team. 2010. The effect of wealth and real income on wildlife consumption among native Amazonians in Bolivia: estimates of annual trends with longitudinal household data (2002-2006). Animal Conservation 13(3):265-274. http://dx. doi.org/10.1111/j.1469-1795.2009.00330.x

Hames, R. B., and W. T. Vickers. 1982. Optimal diet breadth theory as a model to explain variability in Amazonian hunting. American Ethnologist 9:358-378. http://dx.doi.org/10.1525/ ae.1982.9.2.02a00090

Hansen, A. J., and R. DeFries. 2007. Ecological mechanisms linking protected areas to surrounding lands. Ecological Applications 17:974-988. http://dx.doi.org/10.1890/05-1098

Hill, K., J. Padwe, C. Bejyvagi, A. Bepurangi, F. Jakugi, R. Tykuarangi, and T. Tykuarangi. 1997. Impact of hunting on large vertebrates in the Mbaracayu Reserve, Paraguay. Conservation Biology 11:1339-1353. http://dx.doi.org/10.1046/j.1523-1739.1997.96048. $\underline{\mathrm{X}}$

Iwamura, T., E. F. Lambin, K. M. Silvius, J. B. Luzar, and J. M. V. Fragoso. 2014. Agent-based modeling of hunting and subsistence agriculture in indigenous lands: understanding interactions between social and ecological systems. Environmental 
Modelling \& Software 58:109-127. http://dx.doi.org/10.1016/j. envsoft.2014.03.008

Jerozolimski, A., and C. A. Peres. 2003. Bringing home the biggest bacon: a cross-site analysis of the structure of hunter-kill profiles in Neotropical forests. Biological Conservation 111:415-425. http://dx.doi.org/10.1016/S0006-3207(02)00310-5

Kensinger, K. M. 1995. How real people ought to live: the Cashinahua of Eastern Peru. First edition. Waveland Press, Long Grove, Illinois.

Kinnaird, M. F., E. W. Sanderson, T. G. O’Brien, H. T. Wibisono, and G. Woolmer. 2003. Deforestation trends in a tropical landscape and implications for endangered large mammals. Conservation Biology 17:245-257. http://dx.doi.org/10.1046/ j.1523-1739.2003.02040.x

Laurance, W. F., J. L. C. Camargo, R. C. C. Luizão, S. G. Laurance, S. L. Pimm, E. M. Bruna, P. C. Stouffer, G. B. Williamson, J. Benítez-Malvido, H. L. Vasconcelos, K. S. V. Houtan, C. E. Zartman, S. A. Boyle, R. K. Didham, A. Andrade, and T. E. Lovejoy. 2011. The fate of Amazonian forest fragments: a 32-year investigation. Biological Conservation 144:56-67. http://dx.doi. org/10.1016/j.biocon.2010.09.021

Laurance, W. F., B. M. Croes, L. Tchignoumba, S. A. Lahm, A. Alonso, M. E. Lee, P. Campbell, and C. Ondzeano. 2006. Impact of roads and hunting on Central African rainforest mammals. Conservation Biology 20:1251-1261. http://dx.doi.org/10.1111/ j.1523-1739.2006.00420.x

Laurance, W. F., and D. C. Useche. 2009. Environmental synergisms and extinctions of tropical species. Conservation Biology 23:1427-1437. http://dx.doi.org/10.1111/j.1523-1739.2009.01336. $\underline{x}$

Laurance, W. F., D. C. Useche, J. Rendeiro, M. Kalka, C. J. A. Bradshaw, S. P. Sloan, S. G. Laurance, M. Campbell, K. Abernethy, P. Alvarez, et al. 2012. Averting biodiversity collapse in tropical forest protected areas. Nature 489:290-294. http://dx. doi.org/10.1038/nature11318

Levi, T., F. Lu, D. W. Yu, and M. Mangel. 2011. The behavior and diet breadth of central-place foragers: an application to human hunters and Neotropical game management. Evolutionary Ecology Research 13:171-185.

Levi, T., G. H. Shepard, Jr., J. Ohl-Schacherer, C. A. Peres, and D. W. Yu. 2009. Modelling the long term sustainability of indigenous hunting in Manu National Park, Peru: landscapescale management implications for Amazonia. Journal of Applied Ecology 46:804-814. http://dx.doi.org/10.1111/j.1365-2664.2009.01661. $\underline{\mathrm{X}}$

Lima, E. C. 2001. Erros repetidos: a pavimentação da BR-364 e os Katukina. Campos-Revista de Antropologia Social 1:203-214.

Lima, E. C. 2002. Katukina. Pages 169-176 in M. C. Cunha and M. A. Barbosa, editors. Enciclopédia da floresta. Companhia das Letras, São Paulo, Brasil.

Ling, S., and E. J. Milner-Gulland. 2006. Assessment of the sustainability of bushmeat hunting based on dynamic bioeconomic models. Conservation Biology 20:1294-1299. http:// dx.doi.org/10.1111/j.1523-1739.2006.00414.x
Lupo, K. D., and D. N. Schmitt. 2005. Small prey hunting technology and zooarchaeological of taxonomic diversity and abundance: ethnoarchaeological evidence from Central African forest foragers. Journal of Anthropological Archaeology 24:335-353. http://dx.doi.org/10.1016/j.jaa.2005.02.002

Michalski, F., and C. A. Peres. 2007. Disturbance-mediated mammal persistence and abundance-area relationships in Amazonian forest fragments. Conservation Biology 21:1626-1640. http://dx.doi.org/10.1111/j.1523-1739.2007.00797.x

Milner-Gulland, E. J., E. L. Bennett, and SCB 2002 Annual Meeting Wild Meat Group. 2003. Wild meat: the bigger picture. Trends in Ecology \& Evolution 18:351-357. http://dx.doi. org/10.1016/S0169-5347(03)00123-X

Milner-Gulland, E. J., and J. M. Rowcliffe. 2007. Conservation and sustainable use: a handbook of techniques. Techniques in Ecology and Conservation Series. Oxford University Press, Oxford, UK. http://dx.doi.org/10.1093/acprof:oso/97801985303$\underline{67.001 .0001}$

Navarro, J. G. G. 2004. Aprovechamiento de la fauna silvestre en comunidades cashinaua del río Curanja y Purus. Informe Técnico I. World Wildlife Foundation, Lima, Peru.

Norris, D., C. A. Peres, F. Michalski, and K. Hinchsliffe. 2008. Terrestrial mammal responses to edges in Amazon forest patches: a study based on track stations. Mammalia 72:15-23. http://dx. doi.org/10.1515/MAMM.2008.002

Ochoa-Quintero, J. M., T. A. Gardner, I. Rosa, S. F. de Barros Ferraz, and W. J. Sutherland. 2015. Thresholds of species loss in Amazonian deforestation frontier landscapes. Conservation Biology 29:440-451. http://dx.doi.org/10.1111/cobi.12446

Ohl-Schacherer, J., G. H. Shepard, Jr., H. Kaplan, C. A. Peres, T. Levi, and D. W. Yu. 2007. The sustainability of subsistence hunting by Matsigenka native communities in Manu National Park, Peru. Conservation Biology 21:1174-1185. http://dx.doi. org/10.1111/j.1523-1739.2007.00759.x

Oliveira, P. J. C., G. P. Asner, D. E. Knapp, A. Almeyda, R. Galván-Gildemeister, S. Keene, R. F. Raybin, and R. C. Smith. 2007. Land-use allocation protects the Peruvian Amazon. Science 317:1233-1236. http://dx.doi.org/10.1126/science.1146324

Parry, L., J. Barlow, and C. A. Peres. 2009a. Allocation of hunting effort by Amazonian smallholders: implications for conserving wildlife in mixed-use landscape. Biological Conservation 142:1777-1786. http://dx.doi.org/10.1016/j.biocon.2009.03.018

Parry, L., J. Barlow, and C. A. Peres. 2009b. Hunting for sustainability in tropical secondary forests. Conservation Biology 23:1270-1280. http://dx.doi.org/10.1111/j.1523-1739.2009.01224. $\underline{\mathrm{X}}$

Pautasso, M. 2007. Scale dependence of the correlation between human population presence and vertebrate and plant species richness. Ecology Letters 10:16-24. http://dx.doi.org/10.1111/ j.1461-0248.2006.00993.X

Peres, C. A. 2000. Effects of subsistence hunting on vertebrate community structure in Amazonian forests. Conservation Biology 14:240-253. http://dx.doi.org/10.1046/j.1523-1739.2000.98485.x 
Peres, C. A. 2001. Synergetic effects of hunting and habitat fragmentation on Amazonian vertebrates. Conservation Biology 15:1490-1505. http://dx.doi.org/10.1046/j.1523-1739.2001.01089. $\underline{x}$

Peres, C. A., and H. Nascimento. 2006. Impact of game hunting by the Kayapó of south-eastern Amazonia: implications for wildlife conservation in tropical forest indigenous reserves. Biodiversity \& Conservation 15:2627-2653. http://dx.doi. org/10.1007/s10531-005-5406-9

Peres, C. A., and E. Palacios. 2007. Basin-wide effects of game harvest on vertebrate population densities in Amazonian forests: implications for animal-mediated seed dispersal. Biotropica 39:304-315. http://dx.doi.org/10.1111/j.1744-7429.2007.00272.x

Ramos, R. M. 2005. Estratégia de caça e uso da fauna na Reserva Extrativista do Alto Juruá, AC. Thesis. Universidade de São Paulo, São Paulo, Brasil.

Redford, K. H. 1993. Hunting in the neotropics: a subsidy from nature. Pages 227-246 in C. M. Hladik, A. Hladik, O. F. Linares, H. Pagesy, A. Semple, and M. Hadley, editors. Tropical forests, people, and food: biocultural interactions and applications to development. UNESCO, Paris, France.

Redford, K. H., and J. G. Robinson. 1987. The game of choice: patterns of Indian and colonist hunting in the Neotropics. American Anthropologist 89:650-667. http://dx.doi.org/10.1525/ aa.1987.89.3.02a00070

Rist, J., E. J. Milner-Gulland, G. Cowlishaw, and J. M. Rowcliffe. 2009. The importance of hunting and habitat in determining the abundance of tropical forest species in Equatorial Guinea. Biotropica 41:700-710. http://dx.doi.org/10.1111/j.1744-7429.2009.00527. $\underline{\mathrm{x}}$

Rist, J., M. Rowcliffe, G. Cowlishaw, and E. J. Milner-Gulland. 2008. Evaluating measures of hunting effort in a bushmeat system. Biological Conservation 141:2086-2099. http://dx.doi. org/10.1016/j.biocon.2008.06.005

Robinson, J. G. 1996. Hunting wildlife in forest patches: an ephemeral resource. Pages 11-130 in J. Schelhas and R. Greenberg, editors. Forest patches in tropical landscape. Island Press, Washington, D.C., USA.

Robinson, J. G., and E. L. Bennett. 2004. Having you wildlife and eating it too: an analysis of hunting sustainability across tropical ecosystems. Animal Conservation 7:397-408. http://dx.doi. org/10.1017/S1367943004001532

Robinson, J. G., and R. E. Bodmer. 1999. Towards wildlife management in tropical forests. Journal of Wildlife Management 63:1-13. http://dx.doi.org/10.2307/3802482

Rowcliffe, J. M., E. J. Milner-Gulland, and G. Cowlishaw. 2005. Do bushmeat consumers have other fish to fry? Trends in Ecology \& Evolution 20:274-276. http://dx.doi.org/10.1016/j.tree.2005.03.007

Sirén, A. H., J. C. Cardenas, and J. D. Machoa. 2006. The relation between income and hunting in tropical forests: an economic experiment in the field. Ecology and Society 11(1):44. [online] URL: http://www.ecologyandsociety.org/vol11/iss1/art44/
Sirén, A., P. Hambäck, and J. Machoa. 2004. Including spatial heterogeneity and animal dispersal when evaluating hunting: a model analysis and an empirical assessment in an Amazonian community. Conservation Biology 18:1315-1329. http://dx.doi. org/10.1111/j.1523-1739.2004.00024.x

Sirén, A. H., and D. S. Wilkie. 2014. The effect of ammunition price on subsistence hunting in an Amazonian village. Oryx 50:47-55. http://dx.doi.org/10.1017/S003060531400026X http:// dx.doi.org/10.1017/S003060531400026X

Smith, D. A. 2005. Garden game: shifting cultivation, indigenous hunting and wildlife ecology in western Panama. Human Ecology 33:505-537. http://dx.doi.org/10.1007/s10745-005-5157-Y

Smith, E. A., R. L. Bettinger, C. A. Bishop, V. Blundell, E. Cashdan, M. J. Casimir, A. L. Christenson, B. Cox, R. DysonHudson, B. Hayden, P. J. Richerson, E. A. Roth, S. R. Simms, and W. A. Stini. 1983. Anthropological applications of optimal foraging theory: a critical review. Current Anthropology 24:625-651. http://dx.doi.org/10.1086/203066

Soares-Filho, B., D. C. Nepstad, L. M. Curran, G. C. Cerqueira, R. A. Garcia, C. A. Ramos, E. Voll, A. McDonald, P. Lefebvre, and P. Schlesinger. 2006. Modelling conservation in Amazon basin. Nature 440:520-523. http://dx.doi.org/10.1038/nature04389

Souza-Mazurek, R. R. D., T. Pedrinho, X. Feliciano, W. Hilário, S. Gerôncio, and E. Marcelo. 2000. Subsistence hunting among Waimiri Atroari Indians in Central Amazonia, Brazil. Biodiversity \& Conservation 9:579-596. http://dx.doi.org/10.1023/ A:1008999201747

Stearman, A. M. 1990. The effects of settler incursion on fish and game resources of the Yuqui, a native Amazonian society of eastern Bolivia. Human Organization 49:373-385. http://dx.doi. org/10.17730/humo.49.4.906547u862h5x566

Urquiza-Haas, T., C. A. Peres, and P. M. Dolman. 2009. Regional scale effects of human density and forest disturbance on largebodied vertebrates throughout the Yucatán Peninsula, Mexico. Biological Conservation 142:134-148. http://dx.doi.org/10.1016/j. biocon.2008.10.007

Weinbaun, K. Z., J. S. Brashares, C. D. Golden, and W. M. Getz. 2013. Searching for sustainability: are assessments of wildlife harvest behind the time? Ecology Letters 16:99-111. http://dx.doi. org/10.1111/ele.12008

Woodroffe, R., and J. R. Ginsberg. 1998. Edge effects and the extinction of populations inside protected areas. Science 280:2126-2128. http://dx.doi.org/10.1126/science.280.5372.2126 